\title{
Detection of Toxoplasma gondii and Neospora caninum antibodies in cattle in Mosul city , Iraq
}

\author{
B. A.AL- Badrani M.I. AL-Farwachi O.K. AL-Hankawai \\ Coll. of Vet. Med. / Unive. of Mosul
}

\section{Abstract}

The study was conducted on the one hundred sera of local breed cattle in Mosul city, Iraq. All sera were tested for presence of Neospora caninum and Toxoplasma gondii antibodies by using indirect enzyme linked immunosorbent kits. Results showed that $30 \%$ was positive for Toxoplasma gondii while Neospora caninum showed a positive of $20 \%$.Mixed infections were found in one animal only ( $1 \%$ ). This results indicate that Toxoplasmosis is much more widespread than neosporosis in cattle living in the Mosul city, Iraq.

\section{Introduction}

Toxoplasma gondii and Neospora caninum are closely related Apicomplexan parasites which are morphologically similar but possess some structural, molecular and antigenic differences $(1,2)$. They have similar lifecycles with different final hosts, the felids ( 3 ) and canids ( 4 ) respectively, and both parasites have similar intermediate hosts including a wide range of mammals ( $5,6,7$ ). Both parasites causing abortion and fetal abnormality in cattle $(8,9)$. Previous serological investigations have shown that antibodies to both parasites were present in several species including cattle ( 10$)$ , sheep ( 11 ), and dogs ( 12 ). This work is a comparative seroprevalence of bovine toxoplasmosis and neosporosis in Mosul, Iraq.

\section{Material and methods}

A total of 100 sera were collected from local breed cattle ( $3-10$ years old ) from different regions in the Mosul city, Iraq during the period from July 2011 to April 2012. A commercial ELISA kit ( Bio $-\mathrm{X}$ Neospora caninum, Indriect ELISA kits ) for detection of antibodies against Neospora caninum in bovine serum was used, the kit has been supplied from Bio - $\mathrm{x}$ Diagnostics - Belegique. The test uses 96- well microtitration plates sensitized by a purified Neospora caninum protein. The plates odd columns ( $1,3,5,7,9$ and 11$)$ contain the purified protein, where as the even columns $(2,4,6,8,10,12)$ contain a control antigen. we thus have agenuine negative control. Using such a control reduce the number of false positive considerably.All sera were tested according to the manufacturers instructions, then read the optical densities in the microwells using a micro plate reader at a wavelength of 450 nm.ELISA optical density ( OD ) reading were transformed to serum / positive percentage ( $\mathrm{S} / \mathrm{P}$ ) according to a specific equation cited by manufacturer. The sample considered positive if it gives $\mathrm{S} / \mathrm{P} \%>15$ $\%, 10 \%<\mathrm{S} / \mathrm{P} \%<15 \%$ considered doubtful, but S / P \% < $10 \%$ considered negative $. \mathrm{S} / \mathrm{P}=$ Delta OD sample / Delta OD positive X 100 All sera were also tested by a commercial kit (ELISA T. gondii serum screening, Institut Pourquier, Montpellier, France). The serum was positive if more than $50 \% \mathrm{~S} / \mathrm{P}$ was found.

\section{Results}

From a total of 100 cows , $30(30 \%)$ were positive for $T$. gondii and 20 (20\%) for $N$. caninum . One animal (1\%) had detectable antibodies against both $N$. caninum and T.gondii.T. gondii was of higher seropositive in healthy non pregnant cows and more in comparison with aborted and pregnant cows ( Table 1 ). Healthy non pregnant cows had a lower rate of infection than aborted and pregnant cows ( Table 2 ). 
AL-Qadisiya Journal of Vet.Med.Sci. of $5^{\text {th }}$ conference 21-22 Nov. 2012

Vol. 11

No. 3

2012

Table 1: Percentages of seropositive for T. gondii in cattle in Mosul city ,Iraq

\begin{tabular}{|l|c|c|}
\hline Origin of sera & Number of examined & Number of seropositive ( \%) \\
\hline From healthy non pregnant cows & 30 & $17 \backslash 30(56.7)$ \\
\hline From pregnant cows & 35 & $7 \backslash 35(20.0)$ \\
\hline From aborted cows & 35 & $6 \backslash 35(17.1)$ \\
\hline Total & 100 & $30 \backslash 100(30.0)$ \\
\hline
\end{tabular}

Table 2: Percentages of seropositive for $N$. caninum in cattle in Mosul city ,Iraq

\begin{tabular}{|l|l|c|}
\hline Origin of sera & Number of examined & Number of seropositive ( \%) \\
\hline From aborted cows & 35 & $11 \backslash 35(31.4)$ \\
\hline From pregnant cows & 35 & $7 \backslash 35(20.0)$ \\
\hline From healthy non pregnant cows & 30 & $2 \backslash 30 \quad(6.7)$ \\
\hline Total & 100 & $20 \backslash 100(20.0)$ \\
\hline
\end{tabular}

\section{Discussion:}

In the present study 30 out of 100 sera ( $30.0 \%$ ) of cows were positive for the presence of antibodies to toxoplasmosis infection. This study showed lower seroprevalence than prevalence studied by Moreno etal.,1991 ( 13) were found in Spain at $41 \%$, Poland 53\% ( 14) ,Serbia $76.3 \%$ (15) and Brazil 71\% (16). The same prevalence of infection ( $30 \%$ ) in buffaloes also reported in Mosul city, Iraq ( 7 ), While lower prevalence of infection in cattle also reported in some countries such as Tanzania ( 17 ), France ( 18 ) and Malaysia (19).The difference in seroprevalence in cattle in different countries may reflect different climatic factors. Cats are common pets kept in most families in Iraq and often found in public places. An increase in the number of cats causes increase of toxoplasmosis infection (4)In this study the percentages of seropositive were $6.7,20.0$ and $31.4 \%$ in the healthy non pregnant animals, pregnant cows and aborted cows respectivetly. Review of all published data indicate that Neospora caninum is a primary abortifacient in cattle $(20,21)$ and Neospora caninum infection is generally latent and asymptomatic in non pregnant cattle, although bovine neosporosis in pregnant cow is associated with repeated abortion and birth of clinically healthy but persistently infected calves ( 22 ). Several studies demonstrate that chronically infected seropositive cows have an about two - to three fold increased risk of abortion compared to seronegative dams ( $23-24$ ). Thurmond and Hietala (1997) (25) observed a 7.4-fold higher risk of abortion during the first gestation of congenitally infected heifers. The percentage of seropositive values was significantly higher in the aborted animals than in other animals which reflect the high concentration of antibodies against neosporosis, as also in the previous serological studies showed the aborted dams from herd with endemic bovine abortion have higher antibodies against specific antigens ( 26 ).Other researcher has also shown that the high antibody titer are found in post abortion sera and during the second part of pregnancy ( 26, 27 ).In conclusion , the results of the present study suggest that is an important factor in the economic losses of the dairy industry in this region of Iraq, and appropriate management and control strategies need to be practiced by dairy farmers in this area. This could be due to the animals owners unawareness to the vaccination programs and also the regions characteristics. The region is illegal animal trade occur from time to time. further epidemiological studies are needed to provide a better understanding of neosporosis and toxoplasmosis under local conditions. 


\section{References}

1. Dubey, J.P., Barr, B.C., Barta, J.R., Bjerka $^{\circ}$ s, I., Bjo ${ }^{\circ}$ rkman, C., Blagburn, B.L.,Bowman, D.D., Buxton, D., Ellis, J.T., Gottstein, B., Hemphill, A., Hill, D.E., Howe, D.K., Jenkins, M.C., Kobayashi, Y., Koudela, B., Marsh, A.E.,Mattsson, J.G., McAllister, M.M., Modry', D., Omata, Y., Sibley, L.D., Speer, C.A.,Trees, A.J., Uggla, A., Upton, S.J., Williams, D.J.L., Lindsay,D.S., 2002. Redescription of Neospora caninum and its differentiation from related coccidia. Int. J. Parasitol. 32, 929-946.

2. Bjerkas I ; Mohn SF; Presthus J.Unidentified cyst forming sporozoon causing encephalomyelitis and myositis in dogs .Z Parasitenkd. $1984,70: 271-274$.

3. Dubey, J.P., Hattel, A.L., Lindsay, D.S., Topper, M.J., 1988. Neonatal Neospora caninum infection in dogs: isolation of the causative agent and experimental transmission. J. Am. Vet. Med. Assoc. 193, 1259-1263.

4. Hill, D., Dubey, J. P. (2002): Toxoplasma gondii: transmission, diagnosis and prevention. Clin Microbiol Infect. 8: 634-640.

5. Dubey JP, Lappin MR. Toxoplasmosis and neosporosis. In: Greene $\mathrm{CE}$, editor. Infectious diseases of the dog and cat. St. Louis (MO):Saunders Elsevier; 2006. p. 754-75.

6. Rodrigues A.A.R., Gennari S.M., Aguiar D.M., Sreekumar C., Hill D.E.,Miska K.B., Vianna M.C.B., Dubey J.P.. Shedding of Neospora caninum oocysts by dogs fed tissues from naturally infected water buffaloes (Bubalus bubalis) from Brazil. Veterinary Parasitology ; 2004,124, 139-150.

7. Al-Farwachi MA , O. K. AL-Hankawe and O. M. Al-Iraqi. Prevalence of antibodies to Toxoplasma gondii in females buffaloes in Ninavah province, Iraq.Iraqi $\mathrm{J}$ Vet. Med ; 2008, 22(1): 19-22.

8. Boger, L.A., Hattel, A.L., 2003. Additional evaluation of undiagnosed bovine abortion cases may reveal fetal neosporosis. Vet. Parasitol.113, $1-6$.

9. Radostits OM, Gay CC, Blood DC, Hinchcliff KW. Veterinary medicine:A textbook of the diseases of cattle, sheep, pig, goats and horses.10th ed. Philadelphia: WB Sanuders Company 2007: 1317-1322

10. Rahman WA ;Manimegalai V ; Chandrawathani P ; Premaalatha B ; Zaini $\mathrm{CM}$; Comparative seroprevalences of bovine toxoplasmosis and neosporosis in five states in Malaysia. Global Veterinaria. 2011,6 (6) ): 575 - 578.

11. Moreno B, Collantes- Fernadez E, Villa A, Navarro A, Regidor - CerrilloJ, Ortega- Mora LM .Occurrence of Neospora caninum and Toxoplasma gondii infections in ovine and caprine abortions.Vet.Parasitol. 2012 ,161:131-132.

12. Hosseininejad, M.* and Hosseini, F. Seroprevalence of Neospora caninum and Toxoplasma gondii infection in dogs from west and central parts of Iran using two indirect ELISA tests and assessment of associate risk factorsIranian Journal of Veterinary Research,Shiraz University. 2011, 12 ( 1 ): 46- 50 .

13. Moreno T; Martinez- Gomez F; Becerra C . The seroprevalence of bovine toxoplasmosis in Cordoba, Spain .Annals of Tropical Medicine and Parasitol.1991, 85 : 285- 286.

14. Sroka J. Sero-epidemiology of toxoplasmosis in the Lublin region. Annals of Agricultural and environmental Medicine .2001, 8: 25-31. 
AL-Qadisiya Journal of Vet.Med.Sci. of $5^{\text {th }}$ conference 21-22 Nov. 2012

Vol. 11

15. Klun I ; Djurkovic - Djakovic O ; Katic-Radivojevic S; Nikolic A. Cross-sectional on Toxoplasma gondii infection in cattle, sheep and pigs in Serbia: seroprevalence and risk factors. Vet. Parasitol. 2006 ,135:121-131.

16. Santos TR; Costa AJ; Toniollo MC ;Luvizotta G H ; Benetti A H. seroprevalence of anti-Toxoplasma gondii antibodies in dairy cattle ,dogs and human from the Jauuru microregion, mato Grosso State Brazil . J of Vet. Parasitol. 2009 , 161: 324326.

17. Luuk B; Schoonman E; Wilsmore E ; Swai S .Seroepidemiological investigation of bovine toxoplasmosis in traditional and smallholder cattle production systems of Tanga Region, Tanzania . Tropical Anim.Health and Prod. 2009, 4 : 579- 587.

18. Gilot- Fromont E; Aubert D; Belkilani S ; Hermitte P; Gibout O ; Geers R ;Villena I. Landscape herd management and within - herd seroprevalence of Toxoplsma gondii in beef cattle herds from Champagne - Ardenne, France .Vet Parasitol. $2009,161: 36-40$.

19. Normaznah YK; Saniah N; Fuzina M ; Nseem ; Khatijah .Prevalance of antibodies to Toxoplama gondii among farmers and cattle in Gombak District, Selangor, Malaysia - A preliminary report.Tropical Biomedicine 21:157- 159.
No. 3

20. Dubey J.P. (2003): Review of Neospora caninum and neosporosis in animals. Korean Journanl of Parasitology,41, $1-16$.

21. Dubey, J.P., Buxton, D., Wouda, W., 2006. Pathogenesis of bovine neosporosis. J. Comp. Pathol. 134, 267-289.

22. Buxton D., McAllister M.M., Dubey J.P. 2002. The comparative pathogenesis of neosporosis. Trends in Parasitology, 18,546-552.

23. Pfeiffer, D.U., Williamson, N.B., Reichel, M.P., Wichtel, J.J., Teague,W.R., 2002. A longitudinal study of Neospora caninum infection on a dairy farm in New Zealand. Prev. Vet. Med. 54, 11-24.

24. Thurmond, M.C., Hietala, S.K., 1997. Effect of congenitally acquired Neospora caninum infection on risk of abortion and subsequent abortions in dairy cattle. Am. J. Vet. Res. 58, 1381-1385.

25. Schares, G., Rauser, M., So“ndgen, P., Rehberg, P., Bärwald, A., Dubey,J.P., Edelhofer, R., Conraths, F.J., 2000. Use of purified tachyzoite surface antigen p38 in an ELISA to diagnose bovine neosporosis.Int. J. Parasitol. 30, 1123-1130.

26. Quintanilla-Gozalo, A., Pereira-Bueno, J., Seijas-Carballedo, A.,Costas, E.,Ortega-Mora, L.M., 2000. Observational studies in Neospora caninum infected dairy cattle: relationship infection- abortion and gestational antibody fluctuations. Int. J. Parasitol.30, 900-906. 
AL-Qadisiya Journal of Vet.Med.Sci. of $5^{\text {th }}$ conference 21-22 Nov. 2012

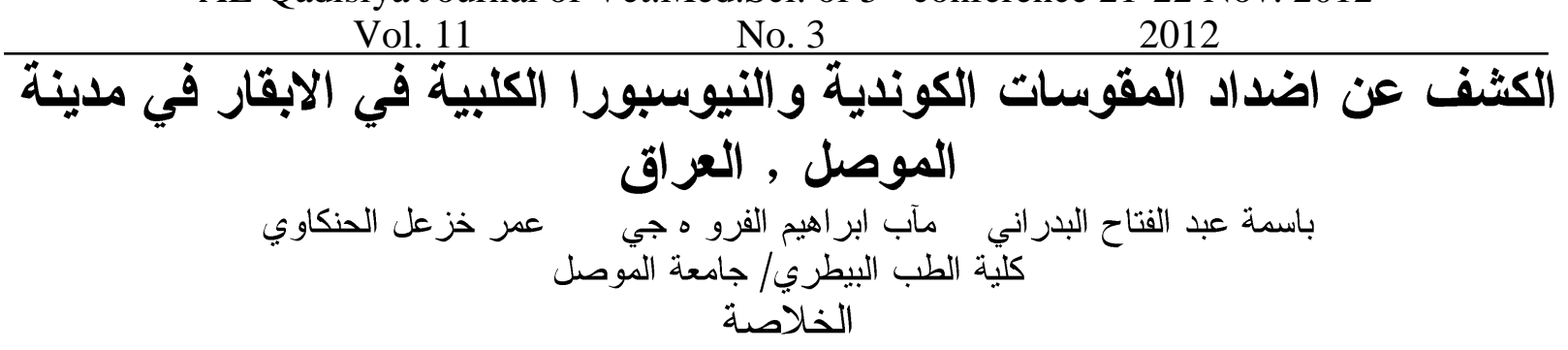

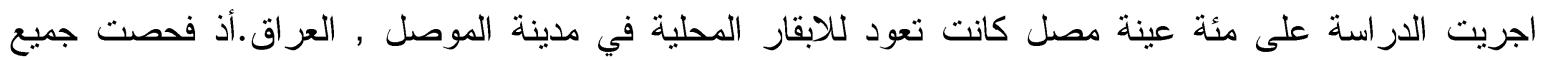

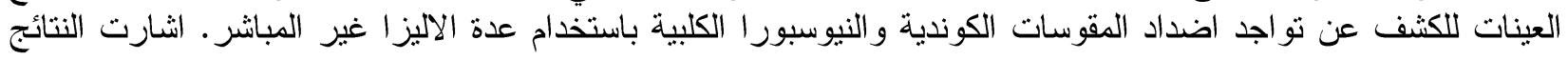

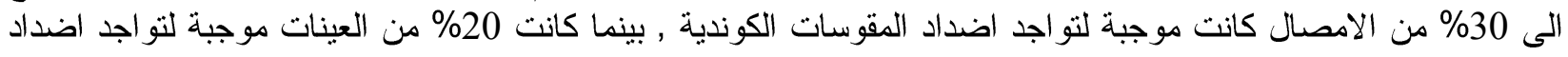

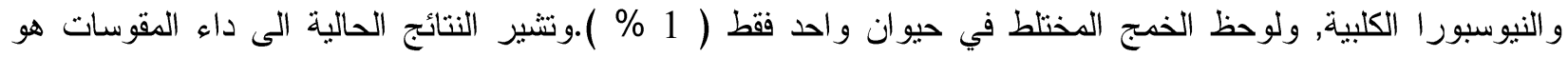
الاكثر انتشار ا من داء النيوسبور ا في الابقار الموجودة في مدينة الموصل فئل ف العراق. 